U.S. Department of Agriculture

Animal \& Plant Health Inspection Service

Wildifife Services

September 2017

Wildiffe Damage Management Technical Series

\title{
European Starlings
}

\section{H. Jeffrey Homan}

Research Wildlife Biologist (retired) USDA-APHIS-Wildlife Services National Wildlife Research Center Fort Collins, Colorado

\section{Ron J. Johnson}

Professor Emeritus

School of Agricultural, Forest and Environmental Sciences

Clemson University

Clemson, South Carolina

James R. Thiele

Wildlife Biologist

USDA-APHIS-Wildlife Services

Lincoln, Nebraska

George M. Linz

Research Wildlife Biologist (retired) USDA-APHIS-Wildlife Services National Wildlife Research Center Fort Collins, Colorado

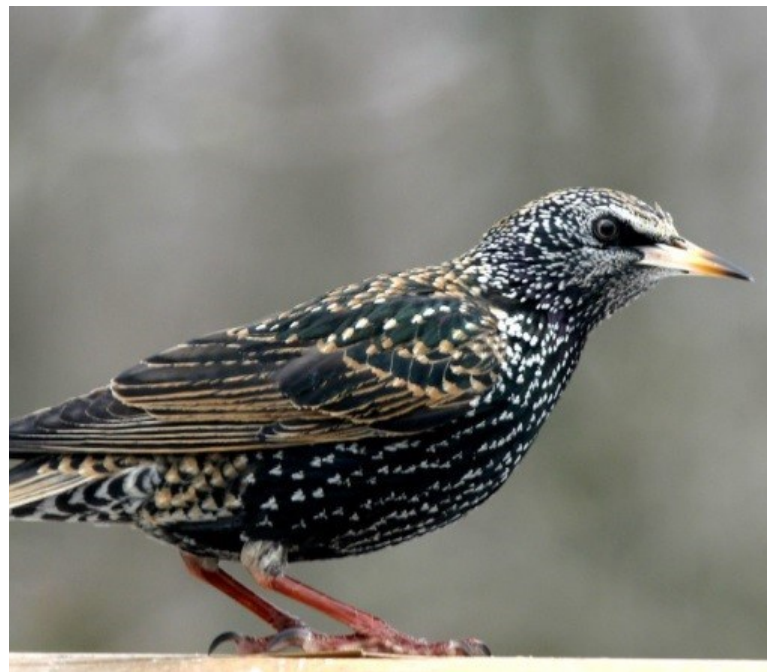

Figure 1. Female European starling in winter plumage.

\section{Human-Wildlife Conflicts}

\section{Quick Links}

\begin{tabular}{|ll|}
\hline Human-Wildlife Conflicts & $\mathbf{1}$ \\
Damage Identification & 6 \\
Management Methods & 6 \\
Economics & 16 \\
Species Overview & 16 \\
Legal Status & 21 \\
Glossary \& Key Words & 22 \\
Resources & 23 \\
Appendices & 25 \\
\hline
\end{tabular}

\section{European starlings (Sturnus vulgaris,} Figure 1) are an invasive species in the United States. The first recorded release of the birds was in 1890 in New York City's Central Park. Because starlings easily adapt to a variety of habitats, nest sites and food sources, the birds spread quickly across the country. Today, there are about 150 million starlings in North America.

Conflicts between people and starlings occur mostly in agricultural settings. Conflicts can occur during winter in urban and suburban environments, especially in business districts.

\section{Crops}

Starlings damage apples, blueberries, cherries, figs, grapes, peaches, and strawberries. Besides causing direct losses from eating fruits, starlings peck and slash at fruits, reducing product quality and increasing the fruits' susceptibility to diseases and crop pests (Figure 2).

Fruit damage begins in early May, with early damage done by aggregated family groups. Flock composition during May and June is often dominated by young-of-theyear. Later in the damage season, 
starlings segregate into flocks consisting almost entirely of either adults or juveniles.

In 2012, field damage surveys were conducted in cherry orchards and vineyards in Michigan, New York, Washington and Oregon. Bird damage to sweet cherries ranged from 3 percent to 25 percent, whereas damage to grapes ranged from 4 percent to 10 percent. Because of their abundance and broad distribution in the U.S., starlings were major culprits in this damage.

That same year, fruit producers from the four states listed above, plus California, were surveyed. Results indicated that annual damage to wine grapes was more than $\$ 70$ million (Figure 3). Grape producers ranked starlings first among three major depredating bird species, which included American robins (Turdus migratorius) and wild turkeys (Meleagris gallopavo).

Other results from the 2012 survey of producers indicated $\$ 51$ million in damages to sweet cherries and $\$ 33$ million to blueberries. Total bird damage for the five types of fruit crops covered in the 2012 survey (blueberries, wine grapes, apples, sweet cherries and tart cherries) was estimated at $\$ 189$ million. Starlings were ranked either first or second among the bird species believed responsible for damaging the five crop types in the survey.

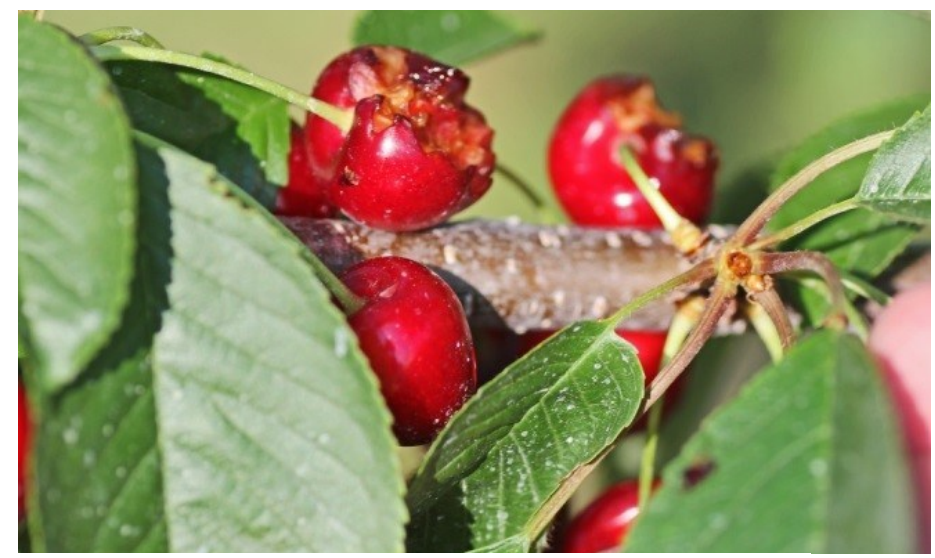

Figure 2. Bird damage to sweet cherries in Michigan.
In the U.S., starlings are not considered serious pests in cereal crops or oilseed crops. They pull sprouts of some grain crops, but damage appears to be minor and intermittent. Producers of sweet corn in several Midwestern states have complained about starling damage during the ripening period (Figure 4). Complaints have risen steadily over time, but the amount of starling damage to fields of sweet corn has not been documented.

\section{Livestock}

Starlings gather at concentrated animal feeding operations (CAFOs) during late fall and winter. Flocks are much larger than those encountered in late summer and are harder to disperse because of a lack of alternative foods. Starlings prefer facilities with open feeder systems which provide easy access to livestock rations (Figure 5).

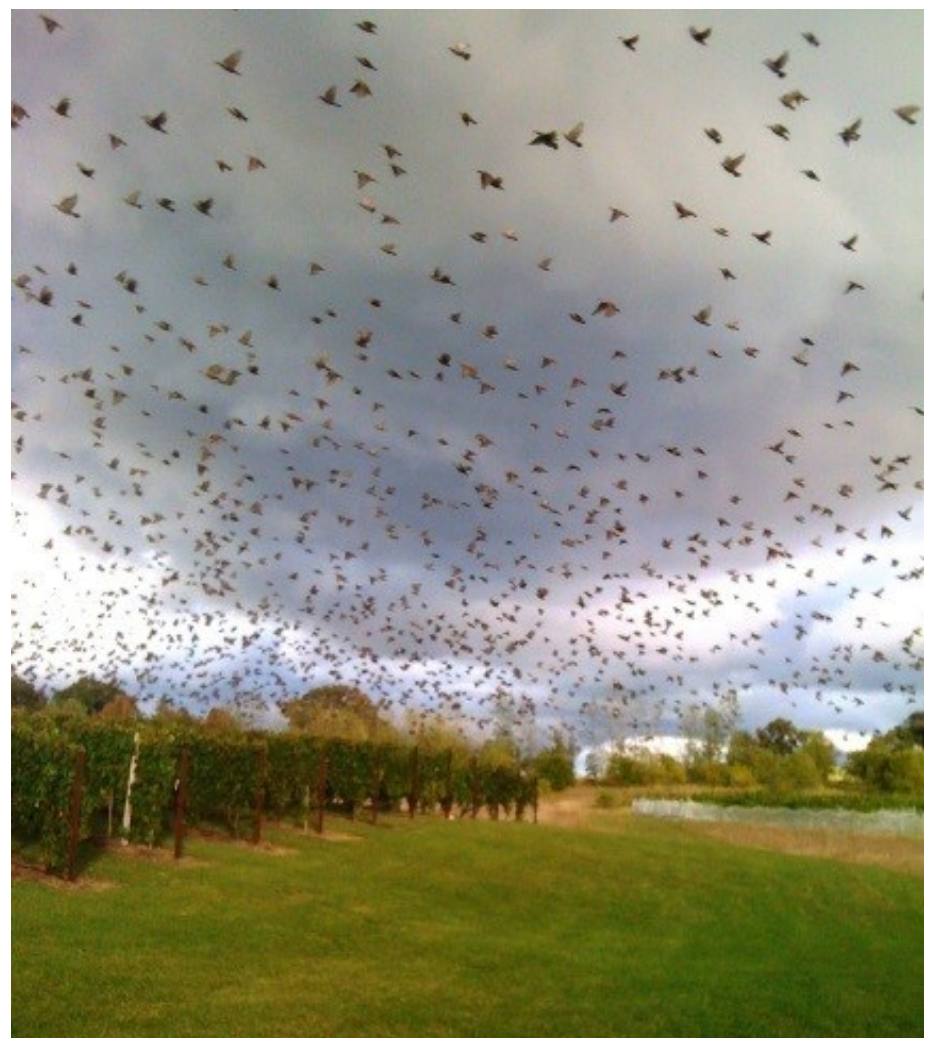

Figure 3. Starlings entering a vineyard. 


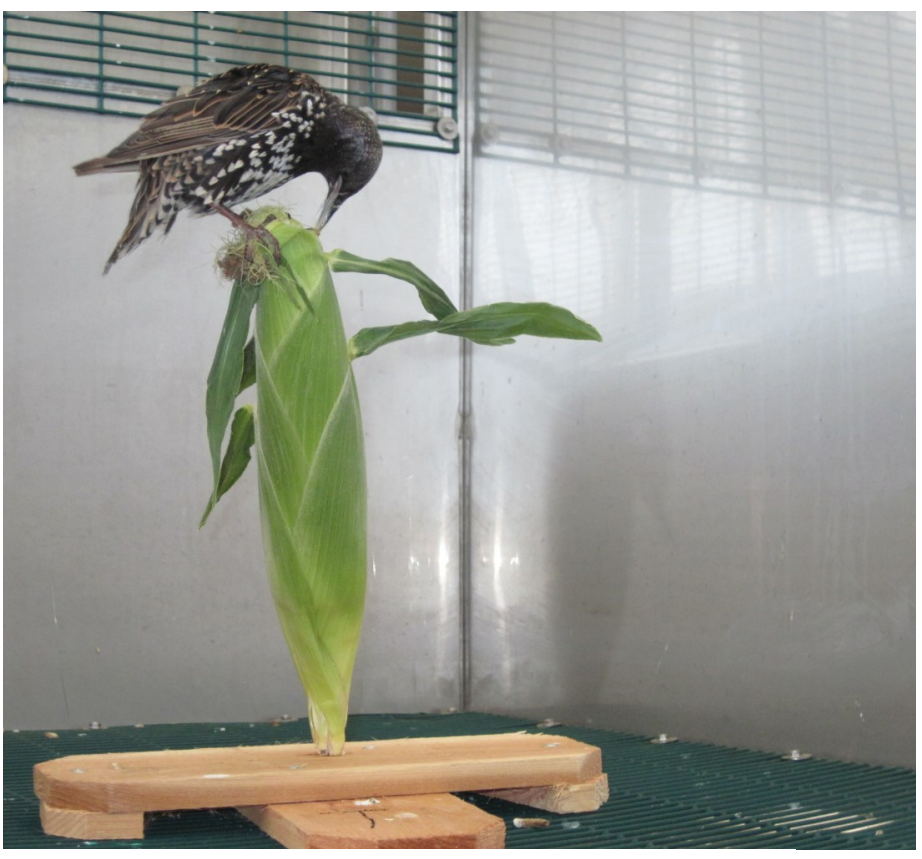

Figure 4. Starling perched on sweet corn during a repellent study with captive birds.

A flock of 1,000 starlings using a CAFO for 60 days during winter will eat about 1.5 tons of cattle feed, representing a loss of $\$ 200$ to $\$ 400$ per 1,000 starlings. About 250,000 starlings that were using a Midwestern feedlot increased the cost of feeding a ration of steam-flaked corn by $\$ 43$ per heifer over a 47-day period between mid-January and March. Costs in lost production (i.e., livestock weight gained per unit feed consumed) over this period was $\$ 1.00$ per animal.

The link between starlings and livestock health is beginning to be understood. Epidemiological evidence suggests that starlings are both biological vectors (e.g., fecal matter) and mechanical vectors (e.g., feet, beaks) of pathogens. Starlings can transmit or amplify several bacterial, fungal, parasitical and viral pathogens. Starlings carry Salmonella spp., several Escherichia coli serotypes, Campylobacter jejuni, Mycobacterium avium, Chalmydophilia psittaci, Flavivirus spp. (West Nile Virus), Avulavirus spp. (Newcastle's disease) and transmissible gastroenteritis (a coronavirus) without showing any symptoms of illness. Pathogens survive in feed troughs, watering troughs and fecal deposits, some surviving for weeks or years. Transmission to livestock occurs through fecal-oral routes, mainly ingestion or licking among animals.

\section{Structures}

In urban environments, the excreta from starling roosts fouls windows, sidewalks, city monuments, landscaping, facades and entryways. The degradation of site quality of downtown environments affects business ambience, public amenities and private property, and may deter commerce.

In addition to creating unsanitary conditions, large deposits of excreta can corrode metals, including motor vehicles (Figure 6) and support structures of buildings and bridges.

Maintenance costs associated with cleaning urban roost sites (Figure 7) are a burden to businesses and city governments. Contracts for a single cleaning of a large skyscraper's windows are about $\$ 50,000$. If an urban roost lasts for a couple of months, costs quickly mount because of multiple cleanings. A starling roost of about 35,000 birds in a city center may cost a business $\$ 260,000$ in cleanup and maintenance over a couple of years.

Lastly, urban and suburban starlings commonly use building exhaust vents as nest sites. Nests can clog vents and create unsafe venting conditions.

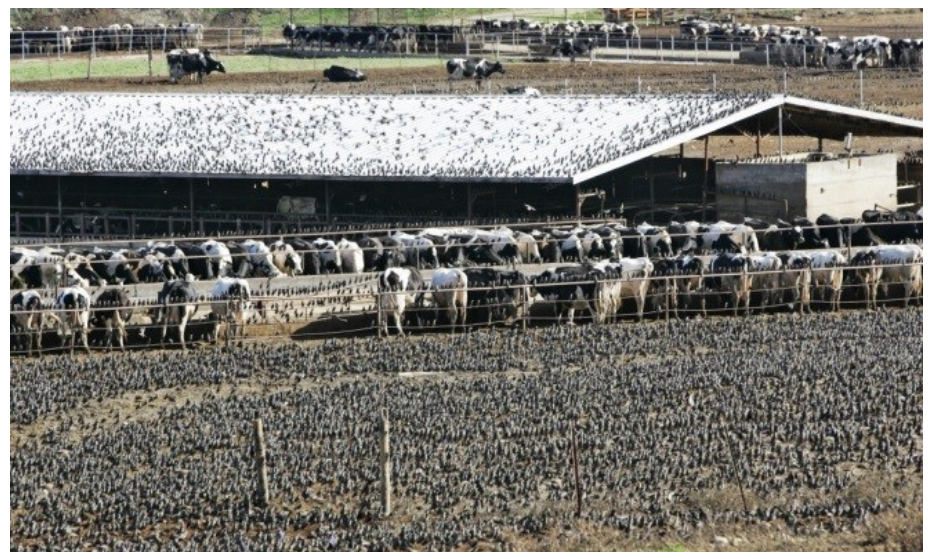

Figure 5. Starlings resting and feeding at a dairy farm. 


\section{Human Health and Safety}

\section{Disease}

Shiga toxin-producing E. coli (STEC) and Salmonella spp. are two important foodborne pathogens in the U.S. that cause more than 1 million clinical illnesses each year. Direct medical costs resulting from infections of $E$. coli and Salmonella spp. are about $\$ 400$ million per year. The total costs to public health from STEC and Salmonella spp. increases to $\$ 3$ billion with the addition of indirect costs (e.g., premature death, loss of productivity).

\section{Salmonella}

At CAFOs, starlings shed Salmonella in their feces. The prevalence of shedding by starlings is relatively low, ranging from 1 percent to 3 percent. This seemingly low rate of prevalence, however, can result in a sizable number of infected starlings when thousands of birds are using a CAFO. Studies at cattle feedlots have shown significant statistical relationships between the number of starlings using a feedlot and the presence of Salmonella enterica in watering and feed troughs. Of the various items studied, including the onsite population size of starlings, cattle stocking rates, facility management, environmental variables and fecal shedding by cattle, onsite population size of starlings best explained S. enterica contamination.

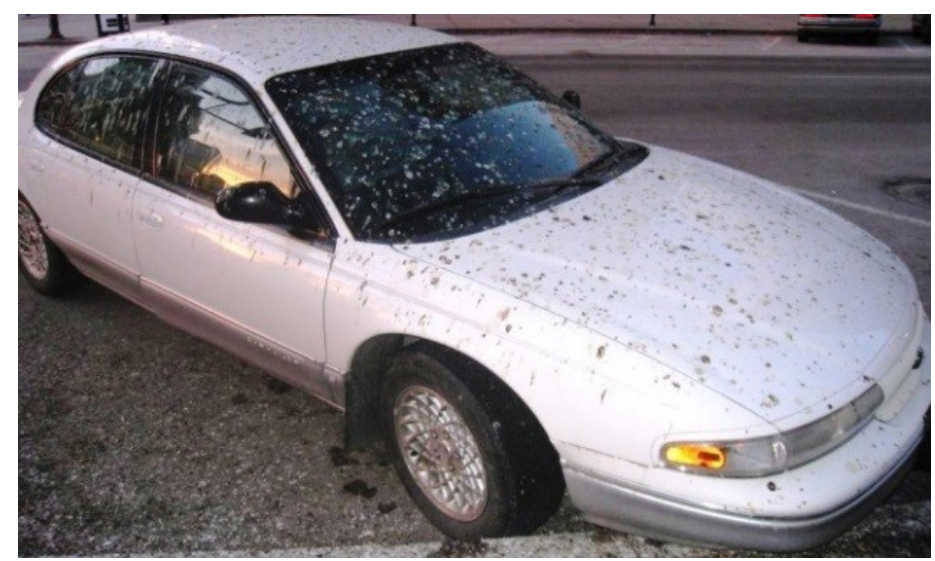

Figure 6. Vehicle parked near an urban starling roost.
Whether starlings are the primary source of $S$. enterica contamination or just amplify its presence has yet to be determined. Preliminary research provides some statistical support for amplification. A reduction of starling populations at cattle feedlots with more than 10,000 birds led to the complete disappearance of $S$. enterica from feed troughs and to substantial declines in prevalence of $S$. enterica in water troughs. At feedlots where starling numbers were not managed, contamination levels of $S$. enterica in feed troughs and water troughs remained nearly the same. Despite these promising results, no difference in the prevalence of S. enterica in cattle feces was detected between sites with and without starling management. This finding suggests that additional factors, besides fecal contamination by starlings, help sustain $S$. enterica once it becomes established in a herd. Multiple biological, environmental and facility management factors (i.e., herd size and age, manure management and disposal, feed storage, access to bacterially-contaminated waters, season and influx of new cattle) could influence the frequency and duration of S. enterica in cattle feces.

\section{E. coli}

Laboratory studies show that fecal shedding from starling to starling, starling to cattle, and cattle to starling can transfer the STEC pathotype, E. coli 0157. Cattle to starling transmission occurs rapidly, taking less than a day. Field studies have provided circumstantial support for starlings

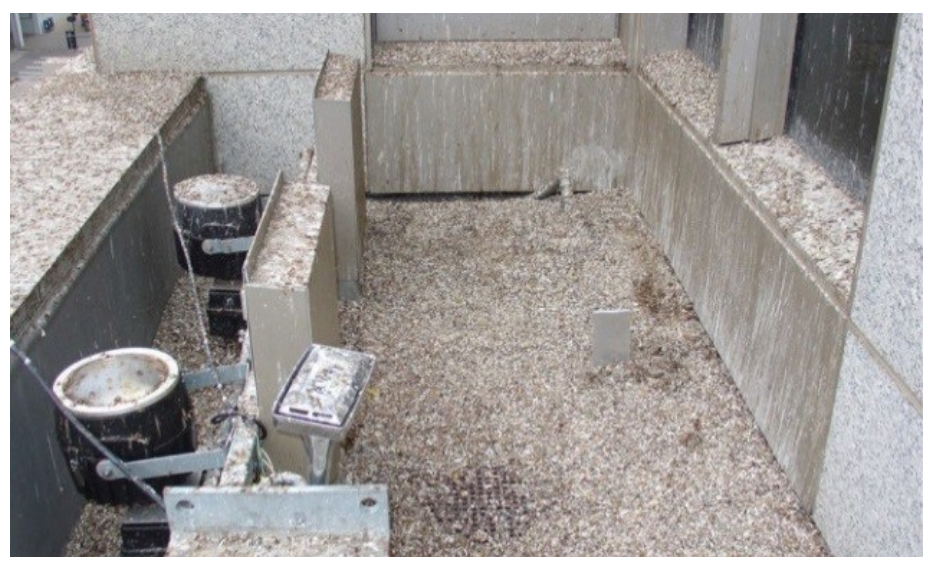

Figure 7. Starling roost located on a skyscraper. 
being both vectors and reservoirs of $E$. coli 0157 . Investigations on the starling's role as a vector of pathogens within and among CAFOs are ongoing.

\section{Histoplasma}

Histoplasmosis is a non-communicable respiratory disease caused by inhaling spores of the soil fungus, Histoplasma capsulatum. The majority of cases occur in the central, southeastern and mid-Atlantic states. About 50,000 to 200,000 cases occur annually, resulting in 800 human deaths. Most infections are asymptomatic and subclinical; between 50 percent and 80 percent of people who live in areas where $H$. capsulatum is common show antibody evidence of exposure, yet only 5 percent develop symptoms severe enough to be categorized as clinically sick. Symptoms include fever, cough, weakness, headaches and muscle aches. Histoplasmosis is hard to diagnose because it resembles influenza. Histoplasmosis has recently emerged as an important opportunistic infection (e.g., disseminated histoplasmosis) among individuals with compromised immune systems.

Soils enriched by nitrogen-laden bird excreta provide an excellent substrate for $H$. capsulatum. Most upland roosts have $H$. capsulatum, but the fungus is not exclusive to starling roosts, as any upland roost can have it. Excreta need to accumulate for more than 3 years before fungal spore densities reach levels high enough to affect human health. Bird droppings must dry out and then be re-wetted before spores can form. Spores cannot form under the highly acidic conditions created from freshly deposited excreta. Massive numbers of spores can be released if soils underneath a roost are disturbed during dry and windy conditions. Severe epidemics of histoplasmosis have occurred in association with the bulldozing of woodland roosts.

Although $H$. capsulatum is associated with soils, it can be found growing inside and around buildings. Thus, starling roosts at industrial sites, manufacturing facilities and abandoned buildings potentially contain the fungus. Commonly used roost sites inside of buildings include stairwells, window ledges, pillars, pipes and beams.

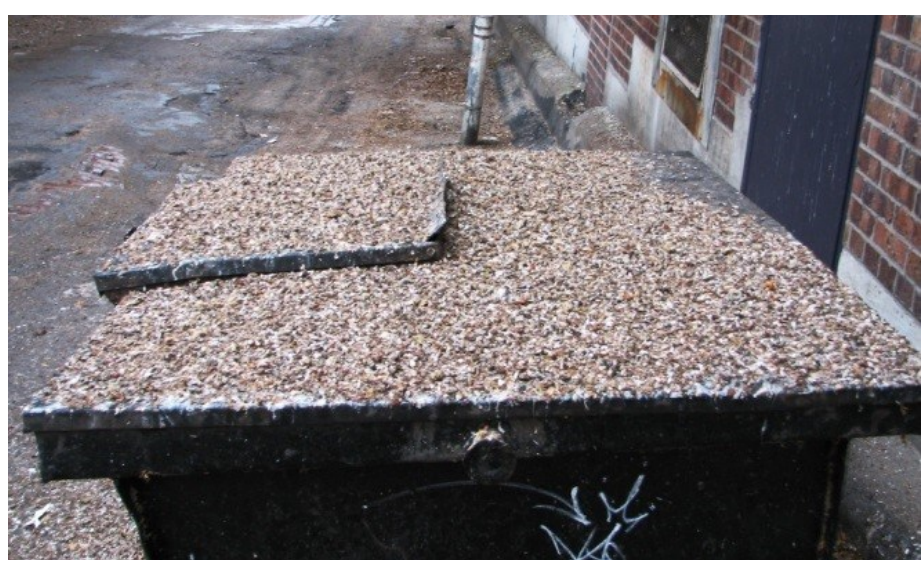

Figure 8. Starling fecal material from a roost above an alleyway in an urban center.

Bats are biological carriers of $H$. capsulatum, and their presence at roosts located inside of buildings dramatically increases the likelihood of finding the fungus. Starlings are only mechanical carriers of $H$. capsulatum. Active roosting sites and fresh excretal deposits encountered on sidewalks, streets (Figure 8) and buildings in urban areas usually do not have $H$. capsulatum.

\section{Airplane Hazards}

Starlings can be hazardous to airplanes because they may roost in the wooded buffer zones that commonly surround airports. Roosts may even form within airport grounds in landscaped areas.

In 1960, a Lockheed L188 Electra (four-engine turboprop) ingested a flock of starlings on takeoff and crashed, resulting in 62 human fatalities and 9 injuries. This remains the worst aircraft incident in the U.S. involving a collision with birds. Post-crash analyses determined that design flaws in the turboprop engines made the engines highly susceptible to damage from bird strikes. Modern engines are more capable of withstanding ingestions of small birds like starlings.

Starlings were identified in 3,203 bird strikes to military and civilian aircraft in the U.S. between 1990 and 2013 (Figure 9). 
Total costs were estimated at $\$ 7$ million. No human fatalities were recorded. Starlings represented only a fraction of the 145,124 bird strikes reported in the U.S. between 1990 and 2013; however, starling roosts remain a substantial management challenge at airports during fall and winter.

\section{Native Species}

Starlings compete with native bird species for cavity nesting sites and may impact species such as eastern bluebirds (Sialia sialis), purple martins (Progne subis), wood ducks (Aix sponsa) and several species of woodpeckers.

\section{Nuisance Problems}

Residents of cities and towns complain about the noise, smell and unsightliness of starling roosts. Most starling roosts in residential areas are temporary aggregations, provided that the roosts do not occur in dense stands of evergreens. If left alone, the roost may last a couple of weeks. Harassing starlings with auditory stimuli as they enter the roost can cause the roost to break up earlier. Temporary roosting sites in cities and towns often are used by several other bird species, including blackbirds, American robins, purple martins, and mourning doves (Zenaida macroura).

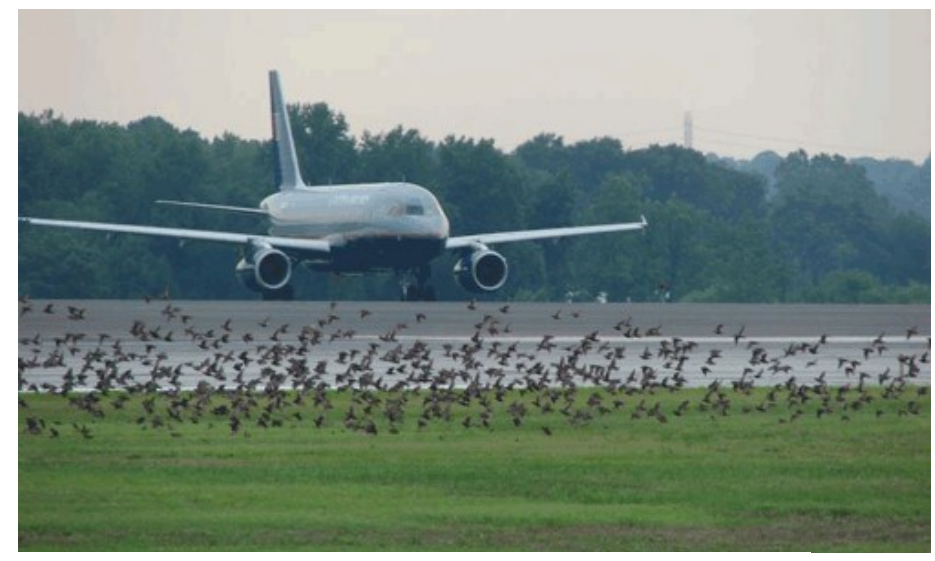

Figure 9. A flock of European starlings in the path of a landing jet.

\section{Damage Identification}

Seeing large starling flocks nearby is often the first indicator that damage may be due to starlings. Starlings damage fruits, such as grapes or berries, by complete removal or partial removal of fruits. Damage to grapes and berries can be similar in appearance to damage caused by American robins, a species of comparable size. Large-sized fruits, such as apples or citrus, are damaged by pecking and slashing. Starling damage to sweet corn is not noticeably different from damage caused by blackbirds, with stripping of husks and damage often concentrated on the top of the ear. Damage to livestock rations is characterized by the removal of food items with highenergy content, including corn rations and fat supplements. In urban environments, large volumes of excreta or "whitewash" on buildings, windows and pedestrian walkways are indicative of starlings.

\section{Management Methods}

Combining multiple methods that affect auditory, gustatory and visual senses is an effective approach for managing pest birds, such as starlings. Starlings quickly habituate to visual deterrents (e.g., Mylar ${ }^{\circledR}$ tape, hawk kites) and audio deterrents (e.g., recorded distress calls). You can prolong and enhance the effectiveness of deterrents by frequently changing their locations and reinforcing them with other methods, such as pyrotechnics, propane cannons, falconry, and shooting.

Netting is the most effective non-lethal method for preventing starling damage to ripening fruits, but the logistics of netting, along with its high initial investment ( $\$ 7,000$ to $\$ 30,000$ per acre, depending on the netting system), typically limits its use to small plots. Large vineyards that grow high-value grapes (e.g., Chardonnay, White Riesling and Cabernet Sauvignon) subject to severe bird damage may be economically justified in using netting (Figure 10). Where netting is cost-prohibitive, a combination of trapping, pyrotechnics and physical harassment may be effective. Trapping can be very effective early in the season because starlings, especially juveniles, are not trap wary. Later, pyrotechnics are more effective when adult-dominated flocks begin to forage. 


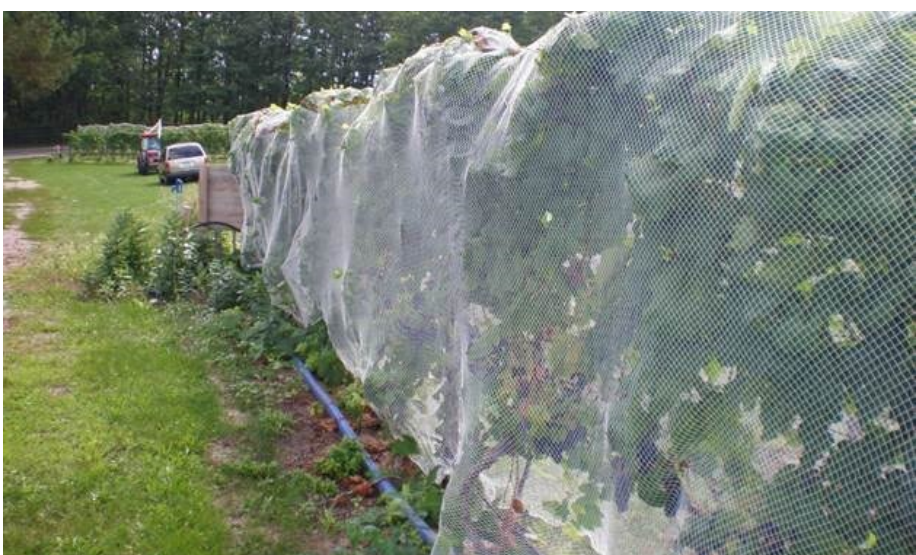

Figure 10. Netting is effective for protecting high-value crops, such as wine grapes.

Fruit damage begins as soon as fruits start to turn color, sometimes as early as June. Varieties of fruit that ripen earlier tend to receive more damage and need more protection because of lower availability of natural food sources early in the growing season.

Timing of damage strongly influences basic strategies of management. For example, non-lethal methods work better for protecting fruit crops than CAFOs because fruit damage usually occurs when there still is an abundance of natural foods, such as soil grubs. By contrast, starling damage at CAFOs occurs during late fall and winter, when natural foods are more scarce.

Minimum population thresholds or damage thresholds for initiating management actions depend on both the effectiveness of the methods being used and the value of the crops being defended. Management thresholds become much lower, of course, as crop values increase.

The avicide, DRC-1339 Concentrate, is effective for reducing damage at large CAFOs. A treatment with DRC-1339 can range from $\$ 800$ to $\$ 5,000$. If only feed losses are used to establish a minimum population threshold for treatment at a CAFO, a population of around 10,000 starlings should be enough to warrant a management action. For example, 1,000 wintering starlings will eat approximately $\$ 200$ to $\$ 400$ of feed if present for 60 days. Successful DRC-1339 treatments will remove 70 percent to 100 percent of the targeted population. Maximum take from a single DRC-1339 treatment rarely exceeds 20,000 birds. Thus, livestock facilities with severe infestations of starlings may require several treatments to cause a noticeable reduction in starling population levels. Minimum population and damage thresholds at orchards and vineyards are harder to estimate due to the varying effectiveness of management methods.

When considering the economic feasibility of a management method, a cost-benefit ratio of 1:2 or greater should be expected. For more information on estimating cost-benefit ratios, please see Appendix 2.

\section{Habitat Modification}

Remove or thin perch sites used by starlings for day and night roosts, including tree stands, dense vegetation (e.g., evergreens), and emergent vegetation growing in wetlands and low-lying areas. Woodlots used for roosting typically have dense canopies with most trees between 20 to 25 years old. Thinning young stands by 30 percent to 50 percent may disperse roosts or prevent roosting. Pruning side branches of roost trees discourages roosting, but avoid topping trees, which results in denser sidebranching. Removal of trees may also be necessary.

Aquatic herbicides are commercially available to thin dense stands of wetland emergents, such as cattails. In some regions, wetlands and dense thickets of bottomlands are highly preferred winter roosting sites. These sites may be located several miles from sites used for daily activities.

The importance of onsite management practices to reduce starling damage at CAFOs cannot be overstated. The primary goal is to limit the availability of food and water to starlings. Starlings forage the most during early mornings and late afternoons before going to roost. Feeding schedules that take these main foraging periods into account can minimize problems. When feeding livestock, use covered feeders or covered areas, such as sheds. Avoid placing feed on the ground, and clean up spilled grains. Cover or enclose exposed feed storage bunks. Timed automatic-release livestock feeders can help 
producers avoid times when starlings are likely to be foraging. For example, switch to afternoon or nighttime feeding schedules, if possible. Mix protein and fat supplements thoroughly into the feed.

Starlings bathe several times a day, so eliminate unnecessary pools of water; also, lower water levels in troughs to prevent starlings from drinking and bathing.

Use feed with forms/pellets greater than 0.5-inch in diameter. These are difficult for starlings to swallow. Starlings will not eat 0.75 -inch $\times 3$-inch extruded pellets. Minimize use of $3 / 16$-inch diameter pellets because starlings can consume these six times faster than other forms, such as granular meal.

\section{Exclusion}

If installed correctly, netting can be highly effective at excluding starlings. Nylon or plastic netting is used to exclude starlings from ledges of multi-storied buildings, but rough edges of building facades can tear netting, making it hard to maintain. Moreover, birds trapped behind the netting may die and decay. Cover undersides of roof beams with netting to prevent starlings from entering and using barns, sheds and other structures. When possible, use netting inside of CAFO buildings to prevent access to rafters, struts and other perching sites.

Netting is cost-effective for protecting vineyards where bird damage is high. If properly maintained, netting can last for 5 or more years. For wine grapes harvested only once a season, tractor-mounted rollers can facilitate the placement and removal of netting over fairly large areas. The cost of labor, netting and construction of an application-removal system for large-area netting is about $\$ 400$ per acre per year, assuming a 10-year lifespan. Highvalued wine grapes (i.e., $\$ 8,000$ per acre for some varieties) may justify the netting of large areas. A producer of high-valued grapes seeking a management cost-benefit ratio of $1: 3$ would be justified in using netting if damage levels were about 15 percent. However, the purchase cost of netting is high, and netting is subject to wear and tear. Grape varieties that continue to grow after ripening may tear nets and hamper net removal.
Table grapes are harvested by hand several times a year. Use a frame to hold netting above the vines so it does not interfere with frequent harvests. The total area to be netted may be too large to be practical. If so, protect varieties that receive the most damage (e.g., fruits of small, dark, sweet grapes), especially fruits that ripen early or are grown near habitat edges. Starlings, however, are not a dedicated edge species and may be found in the center of orchards and vineyards.

Door strips made of either heavy plastic or rubber can exclude starlings from barns and other outbuildings. Use 10-inch wide door strips with 2-inch gaps to block entryways used by people, machinery or livestock. Door strips are useful for protecting feed bunks inside buildings if the strips are mounted on a superstructure. Although netting blocks starling access through entryways, machinery or livestock can easily tear it.

Place $45^{\circ}$-angle coverings of wood, metal or Plexiglas ${ }^{\circledR}$ over ledges to prevent starlings from perching, nesting or roosting. Metal protectors or porcupine wires are available to prevent roosting on ledges or roof beams.

Starlings compete with other bird species for cavity nest sites. Proper nest box construction reduces starling occupation. For eastern bluebirds, use a round $1 \frac{1 / 2}{2}$-inch opening or a rectangular slot cut 4 inches wide by $1 \frac{1}{8}$ inches high. Mountain bluebirds (Sialia currucoides) and western bluebirds (S. mexicana) are larger and require a $19 / 16$-inch opening and a larger inner chamber of at least 5 x 5 inches. Most starlings cannot enter a 1 9/16 -inch diameter hole.

Starlings will evict wood ducks, screech owls (Megascops spp.) and other cavity nesters from nest boxes that must have large openings. Starlings may use boxes as second occupants. Routine maintenance is necessary to keep starlings from nest boxes with large-diameter openings. If starlings are removed early in the reproductive season (April and May), attempts to re-nest in the same box are reduced. Remove starling nests and destroy their contents, including eggs and young. Starlings are persistent, and the removal of nests and contents may need to be done repeatedly. Starlings often avoid using horizontal, artificial nesting cavities constructed of PVC (polyvinyl chloride) pipe 
or sheet metal pipe. For wood ducks, camouflage or darken the pipe to better fit into the environment. Recommended dimensions for wood ducks are a 24 -inch length pipe with a 12-inch diameter. Cap one end and place the entry at the other end. The entry should be semicircular, consisting of a cut 4 inches high by 11 inches wide. Similarly, small artificial nest cavities made of $33 / 4$-inch diameter PVC pipe cut $107 / 8$ inches long with one end capped and an entry hole less than or equal to 2 inches in diameter on the other end can deter starlings while remaining usable by smaller, preferred bird species, such as swallows and bluebirds.

\section{Frightening Devices}

The effectiveness of frightening devices is often dependent upon the operator's persistence and skill, the attractiveness and availability of the crops being eaten by birds, and the availability of alternative foods. Starlings tend to quickly adjust or habituate to frightening devices, especially if devices remain in the same location for extended periods. A combination of several frightening devices working together on visual and auditory senses is more effective than a single device. Vary the location, intensity and types of scare devices to increase their effectiveness. Use frightening devices in early morning and late afternoon, when birds are most actively feeding. Begin using visual and auditory devices before starlings start forming strong attachments to the site.

Although it may take only a few weeks for starlings to habituate to frightening devices, this may be enough time to protect a ripening crop. Effectiveness of frightening devices ultimately depends on having alternative food sources available for starlings to feed on. During winter, when food is more limited, the effect of frightening devices is short-lived.

Many frightening devices are available, including scarecrows, animated scarecrows, recorded calls, propane exploders, battery-operated alarms, pyrotechnics (e.g., bangers, shellcrackers, and screamers), a chemical frightening agent, lights (for roosting sites at night) and Mylar tape.

\section{Auditory and Visual}

Propane exploders are the most popular frightening device because they are relatively inexpensive and easy to use. Propane exploders with automatic timers that turn the exploders on and off each day are useful for reducing habituation, coordinating timing of the explosions with periods of heavy foraging, and preventing noise complaints from neighbors. Use at least one exploder for every 5 to 10 acres in need of protection. Elevate exploders if vegetation canopy is tall enough to block the sound. Use a barrel, stand, or truck bed and move it often to slow habituation. Varying the time between explosions also helps to delay habituation.

Pyrotechnics are more efficient than propane exploders when larger, more inaccessible areas need protection. Pyrotechnics can be launched from pistols or shotguns and travel for nearly 200 yards before exploding, thus bringing the stimulus directly to the foraging site. Pyrotechnics are more labor-intensive than propane cannons because they require an operator. They can be dangerous if misused or mishandled.

Recordings of starling distress calls and alarm calls work best when accompanied by visual stimuli. Starlings (as do most birds) will investigate the source of calls. If starlings cannot associate a call with a visual stimulus befitting their expectations, they quickly learn to ignore the call. Thus, integrating the use of raptor decoys and kites can enhance the effectiveness of calls (Figure 11). Make the scenario even more realistic by including both a raptor decoy and model of its prey within the raptor's clutches. Achieving adequate broadcasting coverage often requires expensive electronic systems; consider their cost when defending a large area against starlings. Lastly, ultrasonic sounds (above $20 \mathrm{kHz}$ ) are not effective in frightening starlings because it is beyond their range of hearing.

Commonly used visual frightening devices include Mylar tape, hawk kites, eye-spot balloons, pop-up scarecrows and inflatable tubes. These devices are inexpensive and easy to use. However, tests of their effectiveness have produced mixed or null results. Mylar tape appeared to 
deter red-winged blackbirds from feeding in ripening grain fields, but not starlings from feeding on ripening blueberries. Combining a visual stimulus, such as a rapidly inflating device (e.g., inflatable tubes, scarecrows) with the auditory stimulus of a propane cannon may be more effective.

Scanning a roosting site with green lasers, which penetrate semi-darkness better than other colors, may help disperse roosts of urban starlings. The effectiveness of the laser is enhanced if accompanied by pyrotechnics. Lasers are ineffective at dispersing birds roosting in dense vegetation.

\section{Chemical Frightening Agent}

Avitrol ${ }^{\circledR}$ (active ingredient 4-aminopyridine) products are restricted use pesticides available in several bait formulations for use as chemical frightening agents. Only certified applicators or those under their direct supervision can purchase or use Avitrol products, and only for those uses allowed on the product's label.

Avitrol baits contains a small number of treated grains or pellets mixed with many untreated grains or pellets. Birds that eat treated bait behave erratically and give alarm cries that can frighten other birds. Birds that eat treated grains or pellets die. Avitrol products are available for controlling starlings at feedlots and staging areas. Non-target birds, such as hawks and owls, may die from eating sick or dead

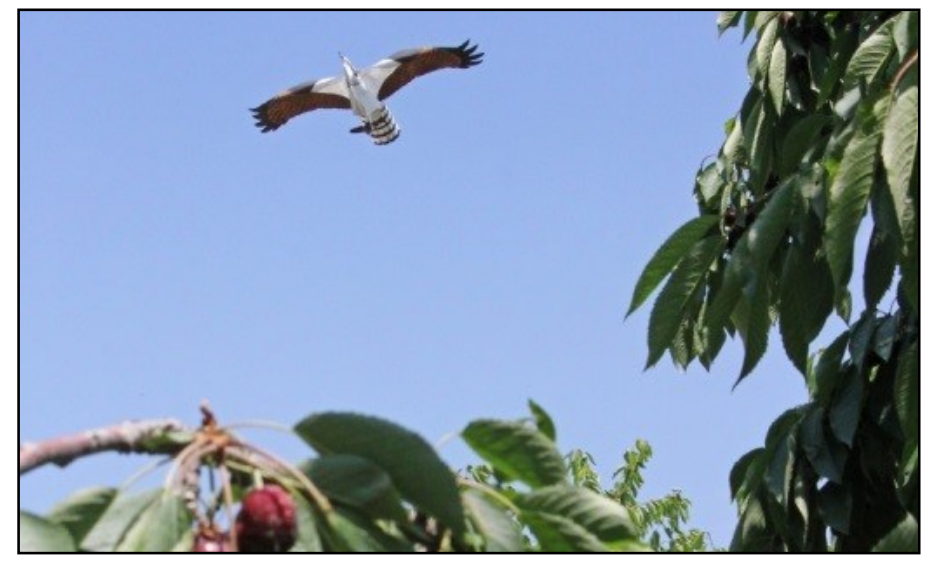

Figure 11. A kite designed to mimic a hawk flies above an orchard of sweet cherries. birds poisoned with Avitrol. Pick up and bury or incinerate any dead starlings at a treated site.

Several Avitrol bait formulations are labeled for starling management at CAFOs. Most are corn-based formulations. The formulation most appropriate for a given situation varies, particularly if large numbers of blackbirds are associated with starlings. The Double Strength Corn Chops formulation is best for mixed flocks of starlings and blackbirds. Starlings can develop bait shyness (bait rejection) to Avitrol baits. Prebaiting for several days with untreated pellets is necessary for effective bait consumption. If starling problems persist, change bait locations to reduce bait shyness. Additional prebaiting may be necessary.

During the winter, the use of frightening agents and devices at CAFOs is generally not effective. Moreover, if the spread of disease is a concern, frightening devices may disperse disease-carrying starlings to other nearby facilities.

\section{Repellents}

Soft, sticky perching repellents consisting of nontoxic polybutenes prevent starlings from roosting on sites such as ledges, roof beams or signage. First, put masking tape on the surface needing protection, then apply polybutenes. The tape makes it easier to remove the polybutenes and allows for application on porous surfaces. Over time, polybutenes lose their effectiveness and may have to be reapplied, if label instructions allow repeated treatments. Label instructions must be followed for any pesticide product containing polybutene. Labor-costs and longevity are issues to consider when using polybutene products.

Several products containing tart or spicy hot ingredients are commercially available and sold as bird repellents. The same ingredients also may be marketed as insect and mammal repellents. Most ingredients used in these products are food-grade and typically have no U.S. Food and Drug Administration (FDA) residue tolerance levels associated with their use. However, some ingredients impart temporary off flavors to the crop following treatment. That said, taste perceptions of birds are far different from those of mammals. For example, capsicum, 
the chemical responsible for the heat in peppers, is a taste irritant in mammals at 1,000 parts per million (ppm). In birds, capsicum is not an irritant, even at very high concentrations.

Several commercial feeding repellents contain the compound methyl anthranilate (MA). The FDA has designated MA as 'generally recognized as safe' (GRAS). MA is used as a flavoring or additive in many foods, drinks and fragrances used by people. It is exempted from FDA food tolerance requirements.

Several MA formulations are available, with MA concentrations ranging from 20 percent to 50 percent. In birds, MA acts as a chemosensory repellent that irritates pain receptors associated with a bird's ability to taste and smell. Methyl anthranilate is registered for use on numerous fruit and grain crops.

At relatively high concentrations $(5,000 \mathrm{ppm}[0.5 \%]$ to $10,000 \mathrm{ppm}[1 \%]$ ), MA is a reliable sensory repellent. However, MA requires multiple applications because it 1) rapidly degrades in the environment, 2) dissolves in the rain, and 3 ) requires strong concentrations to cause irritation in starlings. Costs rise quickly with multiple applications. High-valued crops, such as cherries, blueberries, grapes, and sweet corn, may be good candidates for MA.

An "irritation threshold" for a bird repellent is operationally defined as the concentration necessary to elicit frequent bill wiping, vomiting, head shaking, disheveled feathers, and quick-preening. In aerosol form, MA stimulates adverse reactions in starlings at 8,000 ppm, whereas irritation thresholds in MA solutions presented as drinking water range from 5,000 to $10,000 \mathrm{ppm}$. Starlings avoid foods at MA concentrations of $5,000 \mathrm{ppm}$ or higher.

Current application techniques do not deliver MA at threshold concentrations. Reaching 0.5 percent MA coverage is difficult, especially on fruits or grains surrounded by leafy cover. Residue analysis of MA applied by a backpack sprayer to blueberries showed initial residues of $115 \mathrm{ppm}(0.01 \%)$ immediately following application at a rate of 15.2 pounds of MA per acre. Residues dropped to 18 ppm 24 hours after treatment.
Aerial spraying of rice at 0.7 pounds of MA per acre produced MA residues on rice ranging from $1 \mathrm{ppm}$ to 4 ppm.

The majority of field data on MA applications to fruits has shown either no repellency effect or very short-term effects. More effective formulations or techniques of application are needed to increase MA efficacy.

Although initial studies indicated that MA has potential as an avian feeding repellent on livestock feeds, it rarely has been used in this manner. MA is not cost effective when livestock are fed several times a day. Additionally, feed prices are relatively low compared to the price of MA.

Another repellent is 9,10 anthraquinone (AQ). $A Q$ is a secondary repellent meaning that, unlike sensory repellents, it must be eaten. Birds that ingest AQ suffer digestive discomfort, which they associate with recently eaten foods. $A Q$ is an effective seed treatment on corn, sunflower and rice. AQ is approved under Section 24(c) of the Federal Insecticide, Fungicide and Rodenticide Act (FIFRA) for use in 26 states as a seed treatment on corn. Pesticide residue tolerances must still be established for AQ to be used on food crops.

\section{Shooting}

Shooting is generally not an effective damage management technique for starlings, especially when protecting large areas. Instead, shooting can be used for short-term damage problems or as a reinforcement for other methods, such as frightening devices. Shooting is labor intensive and requires diligence and consistency. Legally, roosts on public lands cannot be disturbed.

Starlings, especially during winter, are active in relatively confined areas where pursuit and harassment with firearms become more feasible than in large field crops or orchards. In addition, starlings have strong site fidelity during fall and winter making them more susceptible to repeated harassment, if a daily program is initiated. 
Before starting a shooting program, observe the behavior of arriving flocks, noting their arrival and departure times, locations of staging sites and loafing sites, and sites used for foraging, drinking and bathing.

Shooting patrols should begin about 30 minutes after the first flocks arrive. Shotguns are the preferred firearm. Continue harassing the birds for about an hour, keeping the birds restless and unable to forage. Resume harassment about 2 hours before sunset. Noise from the shotgun will be enough to move and disturb the birds, but shooting inside of lethal range serves as reinforcement. If the roost site is known and is only a few acres in size, harass the roost beginning about 30 minutes before sunset. Continue harassment by shotgun daily for about a week, then judge the results. If damage does not decline, other methods should be used. Shooters are advised to take a firearms safety course.

\section{Toxicants}

Starlings are highly sensitive to the avicide, DRC-1339 (3-chloro-4-methylaniline hydrochloride). Less than $0.4 \mathrm{mg}$ of DRC-1339 will kill 50 percent of adult starlings (i.e., an $\mathrm{LD}_{50}$ [median lethal dose] value of approximately $4 \mathrm{mg}$ per $\mathrm{kg}$ body weight [bw]). DRC-1339 is a slow-acting toxicant, and unless multiple doses have been eaten over a short period of time, only a few dead starlings will be found at or near a treated site. First symptoms of poisoning are thirst and hypothermia, which can occur within a few hours of eating treated baits. Poisoned starlings may attempt to return early to roost sites or seek cover in dense vegetation along the way. Affected starlings become more lethargic and eventually comatose. Death occurs in 1 to 3 days, likely caused by blood poisoning from kidney malfunction.

The risk of DRC-1339 to non-target species is limited by the selection of bait substrates, bait sizes, treatment dilutions and baiting sites. For example, the size and composition of pellet baits can prevent consumption by nontarget species. Moreover, many nontarget species (such as diurnal raptors) are not particularly sensitive to DRC-1339 with LD50s ranging from 100 to $500 \mathrm{mg} / \mathrm{kg}$ bw.

Compound DRC-1339 Concentrate products are for use only by U.S. Department of Agriculture (USDA) Wildlife
Services (WS) employees or those under their direct supervision. These restricted use products consisting of a 97 percent active ingredient powder are mixed by the applicator with one of several bait substrates, including cracked corn, rolled corn, distiller's grain, milo, rolled milo, poultry pellets, raisins and French fries. Baits not listed on the product's label need Section 24(c) exemptions, which require approvals by state regulatory agencies.

Once prepared, DRC-1339-treated grain bait and pellet bait should be used within 7 days, even when the bait is stored properly. Raisin and French fry baits should be used within 24 hours of mixing.

\section{Prebaiting}

Prebaiting is a necessary and important step before using Compound DRC-1339 Concentrate products. Prebaiting may take a week or longer to attract birds to a baiting site. Prebaiting accomplishes several purposes: 1) familiarizes starlings to the bait substrate; 2) allows for a pretreatment assessment of non-target risks; 3 ) allows for assessment of how much bait to apply when treatment begins; 4) increases the rate at which starlings will eat treated baits once treatment begins; and 5) lures starlings away from their usual feeding areas onsite, which may not be suitable for DRC-1339 use.

The prebait should be the same or very similar to the bait used when applying the DRC-1339 treatment. Although cracked corn works as a bait for starlings, poultry pellets are more attractive, particularly those enhanced with animal fat. You can reduce the number of prebaiting days by either mixing the prebait with foods that starlings are already eating or by using a bait that is already onsite, such as distiller's grain.

When managing smaller populations of starlings, prebait can be placed in containers such as shallow trays, feeder pans and lids, makeshift troughs, and farm wagons. Containers can be easily moved, if needed. Moreover, they allow for faster cleanup of unused bait, and they can be covered at night and during rain events.

DRC-1339 treated bait cannot be placed in areas used by or accessible to livestock and poultry, including feed 
bunks, active pens and coops, and feed storage areas. Baiting sites in CAFO alleyways should be to the sides or in the center of traffic lanes to prevent the crushing and fragmenting of baits. Commonly used prebaiting sites include unused pens and unused feed bunks, alleyways between feed bunks, and open areas near the birds' daytime loafing sites.

\section{Baiting}

Once starlings consistently use a prebaiting site and eat nearly all of the untreated bait being offered daily, use of DRC-1339 treated bait can begin.

On the day that DRC-1339 bait is applied, remove all bait leftover from the prebaiting period. Most starlings will feed heavily at bait sites in the morning after the daily care and feeding of livestock has subsided. DRC-1339 baiting is most effective during cold and clear days, especially when snow cover is present and the ground is frozen.

If winter storms are predicted, wait until the storms have passed before starting a DRC-1339 treatment. Treated baits can be placed on frozen ground or on top of snow, if no melting is occurring. Do not apply treated baits to wet or moist ground.

One pound of pelleted bait using a 1:5 dilution of Compound DRC-1339 Concentrate products will kill about 100 to 200 starlings.

In addition to CAFOs, Compound DRC-1339 Concentrate products can be used for baiting at roost sites and industrial sites, such as grain processing facilities, grain terminals, and food processing plants. The prebaiting and treatment protocols are similar to those used at CAFOs and include: 1) observing bird behavior, 2) selecting a prebaiting site, 3) prebaiting, 4) assessing non-target risks, 5) estimating the amount of prebait taken daily, 6) applying treatment, and 7) cleaning up bait and carcasses.

Starlings often forage on the ground near staging (gathering) areas. These areas may be effective baiting locations. In urban habitats, building rooftops are sometimes used as prebaiting sites.
Starlings may forage at and use sites that are miles away from their roost sites, even when those roosts are located at CAFOs. Starlings depart from roost sites early in the morning, often not returning until late afternoon. Thus, baiting in the early afternoon may sometimes be worthwhile at CAFOs.

The amount of bait eaten on treatment days may be lower than that on previous prebaiting days. In some cases, only half of the bait is eaten. The early onset of symptoms from DRC-1339 at the baiting site may slow down the feeding rate, in addition to scaring away non-poisoned birds. The presence of sickened starlings near the bait site may indicate that the dilution is too strong. This can happen during cold periods, when birds are eating more aggressively. Changing the dilution rate to $1: 20$ or $1: 30$ may increase the amount of take. A computer program is available to WS personnel to help estimate the number of starlings killed.

Often the location of roost sites may not be known. Starlings that spend their day in rural areas sometimes roost in cities and towns. This can result in people encountering sick, dying and dead birds around roost sites and along flight lines to the roost sites. Clean up carcasses around known roost sites and dispose by burial or incineration, depending on State or local regulations. To prevent public alarm, notify neighbors, local authorities (e.g., county sheriff, county health departments), and state and federal resource agencies of baiting efforts. Make it known that sick and dead starlings may be found over a wide area, and provide guidance on the safe handling and removal of carcasses. Once ingested, DRC-1339 is metabolized quickly and most mammalian species (including canines, but not felines) are fairly resistant to DRC-1339. Thus, secondary hazards from scavenging are likely very low.

A successful DRC-1339 baiting operation can remove nearly all starlings from a treated facility provided that the population is not excessively large (e.g., over 25,000 ).

Unsuccessful or apparently unsuccessful DRC-1339 baiting attempts may result from underestimating the initial bird population, bait aversion, degradation of DRC- 
1339, clumping of treated baits in the mix, or a high population turnover. High population turnover should be rare, unless other CAFOs harboring large populations of starlings are within a few miles. To prevent rapid repopulation of a treated facility, all other starling-infested sites within a couple of miles of a DRC-1339 treated site should receive treatments at approximately the same time.

\section{Trapping}

\section{Cage Traps}

Trapping starlings is time consuming and success varies with the time of year, population size and amount of area in need of protection. Trapping with cage (decoy) traps at feedlots and dairies is not cost-effective due to the comparatively low economic value of livestock feed and relatively large numbers of starlings. Trapping starlings at vineyards, fruit orchards and berry farms can be cost effective, especially when flocks of unwary and naïve juveniles are involved.

Cage traps (Figure 12) for starlings should be at least 5 to 6 feet tall to allow the operator ease-of-entry and freedom

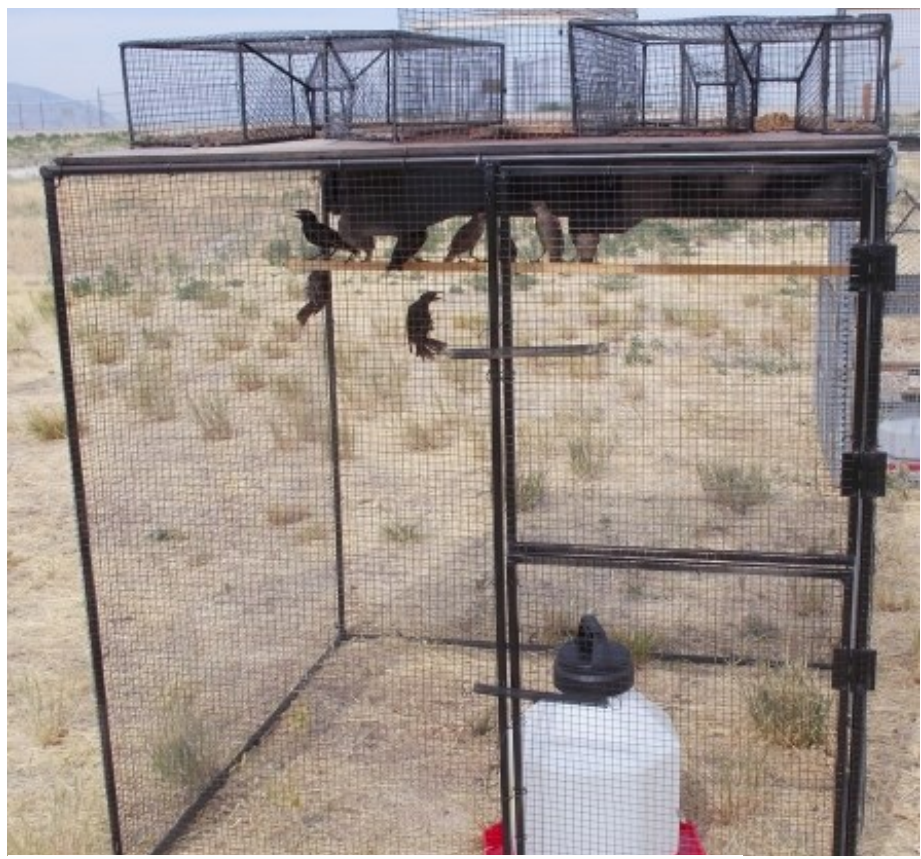

Figure 12. Cage trap used to capture starlings. of movement inside the trap. A convenient frame size is 6 feet $x 8$ feet, covered with wire 1 -inch wide $\times 2$-inches high. Coated wire will cause fewer trap injuries. Traps can be constructed in modular segments and expanded in width and length to increase effectiveness. A small (e.g., 2- $x 2-x$ 3-foot) gathering cage with a sliding door attached to an opening in the trap's upper corner can be used to collect birds.

Transfer captured birds to a cardboard box or canvascovered cage and euthanize with carbon dioxide gas or by cervical dislocation. Examine all dead birds for bands and report any bands found to the U.S. Geological Survey.

Prebaiting the trap will speed up the trapping process. To do this, place the trap in an area frequently used by starlings, leaving the top and door of the trap open. Bait both inside and around the trap with attractive foods, such as fruits, raisins, mealworms or pellets with a high fat content. Provide perches and shallow pans with water to allow for drinking and bathing. Once starlings are using the trap, close it and place bait at the top of the trap near the point of entry and inside the trap directly below the entry. Starlings are not particularly wary of traps, and within a few days should begin entering the trap. Rebait the top and sides of the trap as needed. For smaller traps, keep about six birds as live decoys and euthanize the rest. Increase the number of decoys for larger traps. If not euthanizing the birds, transport and release them more than 20 miles away. A well-maintained decoy trap can capture up to 100 starlings a day, depending on trap size, location, time of year and target population size. Release all captured nontarget birds at the capture site.

Birds in decoy traps must daily be given fresh food (e.g., cat kibbles) and water for drinking and bathing. Provide sheltered perches that protect the birds from sun, wind and precipitation. Replace decoy birds with newly caught birds every few days. Decoy traps have successfully removed starlings from sites where birds were damaging blueberries, figs, grapes, plums, peaches, apples and cherries. Australian crow traps, with slot sizes adjusted for starlings, are also commonly used. Basket-style cage traps (Figure 13) may be more effective for capturing starlings than slot-style traps. 


\section{Nest-Box Trap}

Starlings frequently use nest boxes and nest-box traps may be effective at reducing small populations that cause localized damage. A repeating nest-box trap allows multiple daily captures by funneling captives through a PVC pipe into a holding pen located on the ground.

Check nest-box traps at least twice a day and release nontarget birds immediately. These traps are successful only during the nesting season which typically begins in late February and continues through June.

Larger nest boxes (16 inches $\times 8$ inches $\times 8$ inches) are more attractive to starlings. The entry hole should be 2 inches in diameter. Place the nest-box trap on a pole in an open location or against the side of a building. Traps should be placed at least 10 feet above the ground.

\section{Other Methods}

Sodium lauryl sulfate (SLS) is a surfactant used for managing roosts of pest birds, including blackbirds and starlings. It is exempted from FIFRA registration requirements because SLS is classified as a minimum-risk pesticide under Section 25(b). States can either accept the federal exemption or require state registration of SLS, so check with the appropriate state regulatory agency before using SLS.

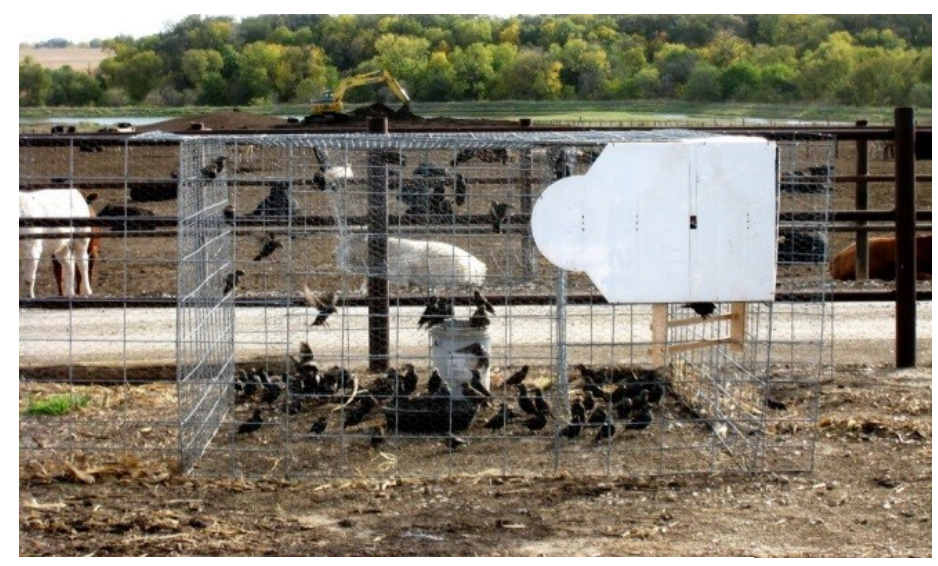

Figure 13. Basket-style cage trap used to capture starlings.
SLS destroys the insulating properties of feathers, causing hypothermia. Wetted birds die as soon as 30 minutes after spraying with SLS. Air temperatures must be less than $41^{\circ} \mathrm{F}$. SLS is classified as 'moderately toxic' to some species of aquatic invertebrates, and may harm plants, thus SLS is for use only on upland roosts and cannot be sprayed over bodies of water or in areas of direct runoff. SLS can damage ornamental plantings and affect plant growth. Before using SLS, the roosts must be observed for non-target species. Spraying is not allowed if non-target species are using the roost. Several field trials with SLS were conducted in southeastern Missouri between 2005 and 2007 using ground-based sprayer systems. The systems consisted of 30-foot tower(s) with either 1 or 4 sprinkler heads, each capable of covering a 2,000-square foot area (i.e., 50-foot diameter circle). A pump delivered water at 6 gallons per minute per sprinkler head. Up to 12,000 starlings and 3,000 blackbirds were killed at a 50,000-bird roost during a single SLS spray using 4 sprinkler heads. The system delivered 21 gallons of SLS (Stepano ${ }^{\circledR}$, Stepan Co, Northfield, IL), along with 2,100 gallons of water over a 1.5 hour period. Poor results were obtained in 3 of 8 roost sprays using SLS and were attributed to low water quality and pump malfunction.

Falconers and their birds of prey may be used to harass starlings from crops. It is labor intensive and expensive, and may cost more than $\$ 500$ per day. Most falconers prefer to use their birds in fairly open habitats, where chances of injuries to the falcons are low. Blueberries and other types of high-value fruits with shrubby habits are more fitted to falconry than tree fruits. Birds are accustomed to seeing birds of prey during their daily lives, and the effect of falconry may be short-term. Installing falcon nest boxes at orchards and vineyards, especially for the American kestrel (Falco sparverius), provides an inexpensive alternative to falconry (Figure 14).

\section{Handling}

No special precautions are needed when handling starlings. Use latex gloves and wash hands with sanitizer after handling. 


\section{Euthanasia}

Cervical dislocation with needle-nose pliers can be used for small numbers of birds. For large numbers, use a sealed container and carbon dioxide. Death from asphyxiation occurs within 5 minutes once the container fills with gas.

\section{Disposal}

Often burial is sufficient, but check your local and state regulations regarding disposal of carcasses.

\section{Economics}

Starling damage reported to the USDA's Wildlife Services program averages less than $\$ 2$ million per year, but this is a fraction of all starling damage. Agricultural damage alone is estimated currently at $\$ 1$ billion per year. Other damage, such as costs for cleaning and maintaining city centers near roosts, veterinary care and loss of production at CAFOs, and public health care, are unknown. A complete inventory of all economic damage likely would show that the starling is the most economically harmful bird species in the United States.

Economic impacts of starlings on livestock herd health probably are substantial. A survey of dairy producers in Pennsylvania in 2009 suggested that veterinary costs at dairies with starling flocks numbering between 1,000 and 10,000 birds were 38 percent higher ( $\$ 91$ per cow per year) than at dairies without starlings (\$66).

Even if starlings play only a minor role in the transmission and amplification of pathogens between animals and among CAFOs, they would still have a major economic impact because of the enormity of industry-wide costs of herd diseases. For example, annual costs in the U.S. from gastrointestinal diseases in livestock caused by $E$. coli spp. (e.g., scours) and M. avium (Johne's disease) were $\$ 600$ million. The average cost of an outbreak of Salmonella among dairy cattle is $\$ 4,000$ per farm per incident. Because salmonellosis is a far more common affliction in livestock than either $E$. coli or $M$. avium, annual costs from this disease likely exceed the $\$ 600$ million yearly loss from scours and Johne's disease.

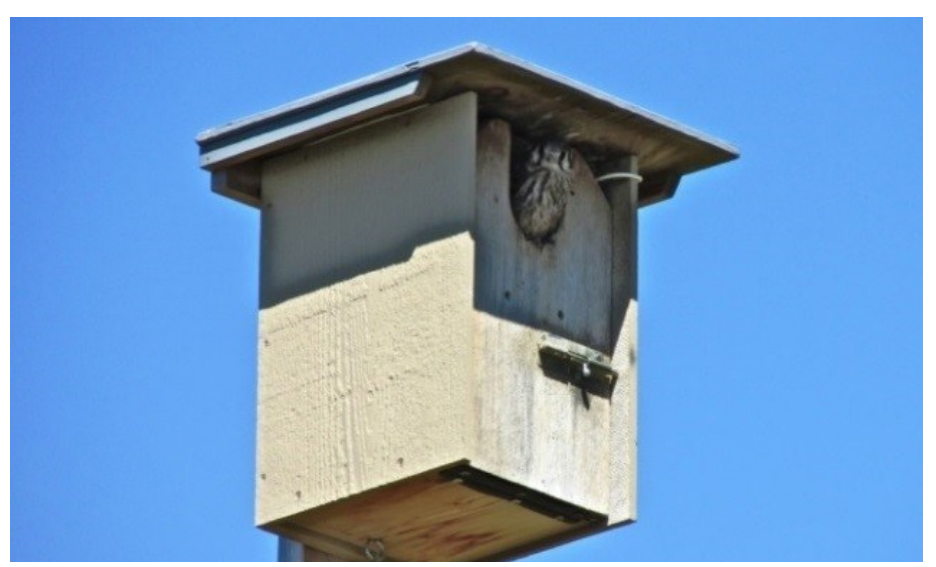

Figure 14. A young American kestrel (Falco sparverius) looks out from a nest box on the edge of a sweet cherry orchard.

Not all studies have shown a correlation between starlings and livestock disease or production. In two years of testing at Western Kentucky University, neither pigs nor cattle were adversely affected by long-term exposure to livestock feed which was heavily contaminated with starling excreta. No significant differences in weight gain or feed efficiency (weight gain:feed offered) were detected between groups provided contaminated feed and clean feed. In addition, there were no observed differences in feed rejection rates or incidences of disease.

\section{Species Overview}

\section{Identification}

European starlings are in the Sturnidae family. During winter, starlings often associate with flocks of blackbirds (Family Icteridae) and sometimes are misidentified as blackbirds. Starlings are not taxonomically related to blackbirds.

Starlings are powerful fliers with triangular-shaped wings. Top flight speeds may reach 50 miles per hour. Unlike blackbirds, undulations between wing beats are typically small, which aides in identification at a distance. Starlings sometimes glide in circular patterns multiple times before landing. 


\section{Physical Description}

Starlings are glossy, dark-colored birds (Figure 15). Females are duller and less glossy than males. Juveniles are tan until they molt in early fall, after which they resemble adults. During winter, body feathers have white speckled tips that wear away by summer. Starting in late winter, iridescent hues of green and purple become prominent in males on feathers of the head and neck; feathers on the throats of males are narrow and long compared to females. Mandibles are narrow and longish $(3 / 4$ inch). Both sexes have bright yellow mandibles beginning from late December through June. Mandibles become dark after June. In the yellow-mandible phase, the lower mandible of females may have a pale pink spot at the base; in males, the spot is pale blue. A light-colored eye ring may surround the iris of adult females. Adult males have uniformly brown-colored eyes with no eye ring.

Starlings are compact birds with a rounded body and short tail. Overall length is 8 inches. Average weight is 3 ounces, with females 10 percent to 20 percent smaller than males.

\section{Range}

Starlings are native to Europe, southwest Asia and northern Africa. Starlings were introduced repeatedly in the New World from the mid to late $19^{\text {th }}$ century. Documented

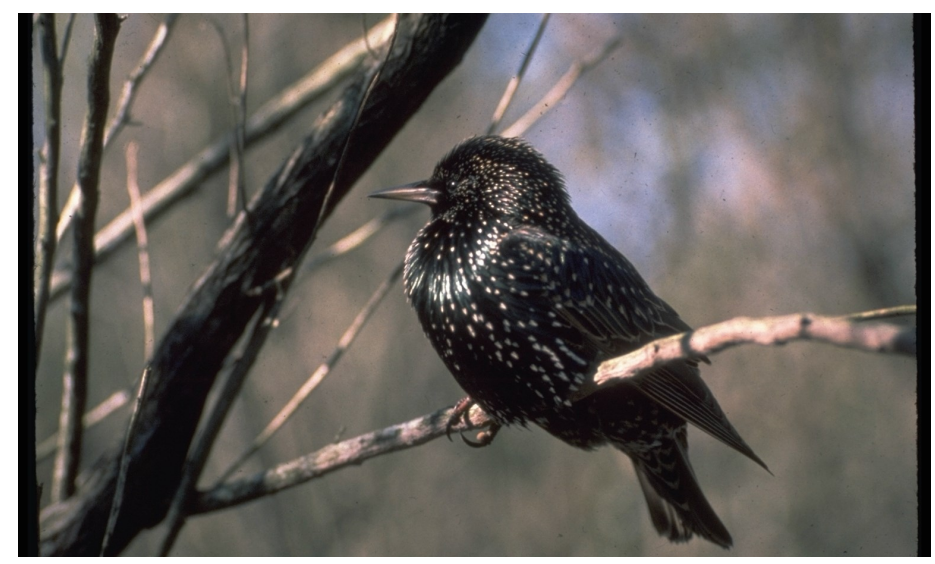

Figure 15. Male European starling. introductions occurred in Oregon and New York. The only successful introduction was in New York City in the late 1890s, when 16 pairs survived initial release and reproduced. By 1942, starlings were observed on the West Coast. They now inhabit all of North America (Figure 16). Their range extends southward to the Bahamas, Central America, Yucatan Peninsula, Puerto Rico, Jamaica and Cuba. There are no subspecies in North America. Genetic analysis indicates that all starlings in North America descended from the New York City introduction.

\section{Voice and Sounds}

Male territorial song consists of an underlying liquid gurgle lasting for about a minute. At various points in the song, the gurgling is interrupted by short ascending or descending whistles. Females likewise sing, but more so in the fall.

Their call repertoire consists of about 10 calls used for indicating their whereabouts, alarm, anxiety, distress and aggression. Calls include chattering, trills, guttural rolls, clicks and screeches.

Starlings are good mimics and imitate many sounds from their environment, including bird calls and traffic sounds. With training, a starling can imitate the human voice.

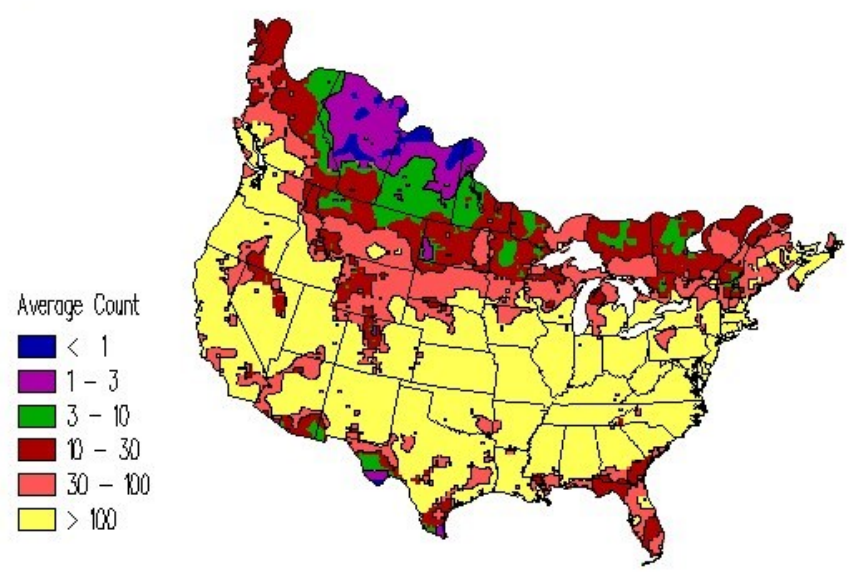

Figure 16. Starling wintering areas in the United States based on the National Audubon Society's Christmas Bird Count. 


\section{Reproduction}

Starlings are monogamous with annual pair bonds lasting throughout the reproductive period. Sexual maturity occurs at 1 year, but first-year birds may fail in their attempts to establish reproductive territories because of competition from older, more experienced birds.

Depending on latitude, the reproductive period lasts from late March through early July. Clutch size is 4 to 7 eggs, with an average of 5 eggs. The incubation period lasts approximately 13 days. Females incubate the eggs, but males sometimes guard the eggs during the female's absence. Both parents feed the young, making up to 20 trips per hour. Nestlings begin to thermoregulate 13 days after hatching and will fledge about 8 days later. South of $48^{\circ} \mathrm{N}$, two clutches are often attempted, with a second attempt initiated by 60 percent of females. Production from first nesting attempts accounts for about 80 percent of yearly production. The percentage of nests that fledge at least one bird ranges from 48 percent to 79 percent. Once established on a successful breeding territory, one or both pair members may return year after year. Offspring will disperse widely to find new breeding territories.

\section{Nesting}

Starlings prefer to use natural cavities, woodpecker cavities and birdhouses. They use nooks and crannies of various human-made structures, including vents, rafters, soffits, lampposts and signage bracing. Territoriality is confined to the immediate area of the nesting site.

Both parents build the nest, which is composed of a mixture of long grasses and other vegetation. Starlings may incorporate miscellaneous items such as cloth, string, plastic, feathers and fresh vegetation into the basic nesting material. The nest cup is 3 inches in diameter and 2.5 inches deep. Eggs are pale blue.

\section{Mortality}

The average life span of a starling is 3 to 4 years. The longest lived starling recorded for North America was 17 years old. Annual mortality is 40 percent to 50 percent, but varies from 30 percent to 80 percent depending on location and weather conditions. Adult females have higher mortality rates than adult males. Approximately 80 percent of fledged young do not survive to reproduce. Mortality rates are greater in fall and winter because of migration, scarcity of natural foods and inclement weather.

Causes of mortality include disease, predation and starvation; none of these are believed to regulate the population. The major limiting factor may be the availability of nest sites.

Each year, 60 to 75 million starlings die of natural causes. Lethal control programs by USDA WS annually take 1 to 3 million starlings. Most are taken during late fall and winter at CAFOs for agricultural protection.

\section{Population Status}

The breeding population estimate for starlings in North America ranges from 60 to 150 million and may reach over 200 million by early fall. Although in long-term decline according to indices by the North American Breeding Bird Survey (BBS), the population in North America has remained relatively stable over the last 2 decades. According to BBS indices, only red-winged blackbirds (Agelaius phoeniceus) outnumber starlings.

\section{Habitat}

Starlings are a peridomestic species, preferring to live in human-altered landscapes. They are adaptable and thus able to exploit numerous agricultural, urban and suburban habitats. Occasionally, they are found in remote areas, particularly near seaside cliffs.

\section{Behavior}

From April through June, starlings either pair up with a mate or form small, non-breeding groups consisting of less than 100 birds. Individual family groups begin to aggregate within a few weeks after fledging. By June, aggregations may exceed 1,000 birds with flocks composed mostly of juveniles. Age classes coalesce by winter, but flocks may separate by sex. At preferred habitats such as CAFOs, flocks may consist predominately of males, sometimes more than 75 percent males. 
Starlings leave their roosts at sunrise. Departing birds generally take a direct route to foraging sites, rarely stopping. If CAFOs are being used, starlings may group nearby waiting for human activities to subside before going onsite. Foraging sites usually lie within 15 miles of the roost, but may be up to 50 miles away. The majority of starlings arrive at their foraging sites within a couple hours of sunrise.

Throughout fall and winter, foraging sites usually are centered on food sources provided by people, including landfills, granaries, food processing plants and CAFOs. These foraging areas are quite small, averaging only a few square miles. Starlings may use the same areas for several weeks or longer during winter.

By late afternoon, starlings begin a leisurely return to their roost. Returning flights can take up to 2 hours to complete, with several foraging stops along the way. Starlings may pass over smaller roosts, some lying closer to the main areas of daily activity, to reach larger roosts lying farther away. Flight lines leading toward large roosts may become obvious about an hour before sunset.

Flocks often stage near the roost site using wooded areas, power lines, bridges, industrial superstructures and other sites with plentiful perches. Forays to nearby open grounds occur during the staging period, with birds briefly feeding. Birds begin entering the roost about 30 minutes before sunset. Starlings may use a large roost consistently for weeks or months.

Urban roost sites in city centers are spread across several urban features, including multi-storied buildings landscaping (especially, evergreens), monuments, signage bracing, superstructures and overpasses. Urban roosts are often satellite roosts, lying within a few miles of a larger, main roost. Locations of main roosts are usually in secluded urban areas, where public access is limited. Major roosts may be less than 5 miles from the urban city center roost. Birds switch occasionally between the satellite roost and main roost. Main roosts are found in industrial parks, landscaped commercial complexes, abandoned buildings, recreation areas, railroad yards, woodlots, wetlands, bridges and wooded buffer zones (Figure 17).
Main roosts in urban areas can harbor more than 100,000 birds and be difficult to find. For example, a 100-yard section of a 4-lane railroad overpass in Omaha, Nebraska, held approximately 70,000 starlings during January. Urban roost sites are devoid of birds throughout the day; however, excretal whitewash on perching sites will indicate that a site could be a major roost.

In suburban areas, starlings roost in conifer stands of residences and businesses, tree groves in parks, and in vegetated lowlands. Suburban roosts are typically smaller than urban roosts, consisting of just a few hundred birds. Although suburban roosts are smaller than urban roosts, many of them can be scattered throughout the suburban landscape.

Urban roosts typically contain 10,000 to 30,000 starlings. Morning departures from urban roosts are difficult to track because starlings leave at first light and break into smaller flocks often going in several directions. Urban starlings use surrounding industrial parks, recreational areas, granaries, landfills, and suburban areas throughout the day. Very few starlings remain within the urban area proper. Outlying agricultural habitats within 25 miles of an urban roost may be used. Upon returning to an urban roost, starlings stage in secluded industrial areas and commercial areas within a few miles of the roost site.

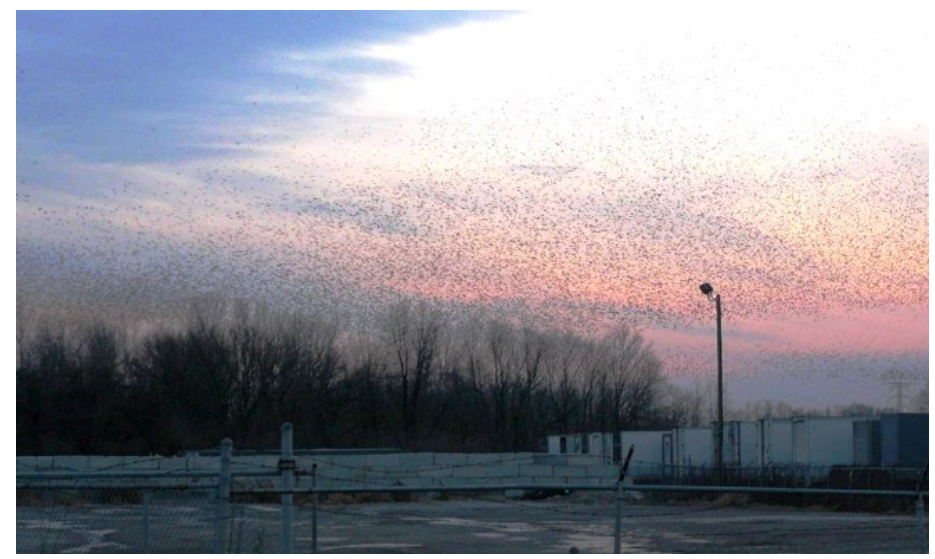

Figure 17. Starlings entering a woodlot roost near Indianapolis, IN. 
In agricultural landscapes, starlings often use wildlife refuges and game management areas for roosting. Wetlands with dense stands of emergent vegetation can be a preferred roosting habitat for mixed-species flocks, including blackbirds, robins and starlings. Thick stands of evergreens also are used. Roost sizes in agricultural landscapes can exceed 1 million birds during winter and attract flocks from over 50 miles. Starlings may also use CAFOs as roost sites. A CAFO can host a few hundred to a few thousand roosting starlings, depending on its size. Starlings that roost at CAFOs do not necessarily use these sites for daytime activities, leaving the CAFO shortly after sunrise and not returning until afternoon.

In the Great Plains Region of the central and western U.S., wintering populations of starlings are highly concentrated because of the vast amount of treeless areas and the low densities of towns and cities. Here, CAFOs become focal points for daytime activities. Larger CAFOs can host hundreds-of-thousands of starlings per day (Figure 18).

Smaller facilities host from 1,000 to 10,000 birds. Starlings may use the same CAFO throughout winter, rarely visiting other CAFOs unless they occur within a few miles.

In southern and mid-latitudinal regions of the U.S., flocks at CAFOs begin to thin by late January or mid-February, because resident starlings begin establishing breeding territories. At the same time, migrant populations experience migratory restlessness. Changes in activity areas, longer daily movements and use of other CAFOs begin in February.

Starlings are short-distance migrants. Most travel only a few hundred miles to reach breeding territories; however, some travel more than 1,000 miles. Leg bands collected from a wintering population of starlings in Omaha, Nebraska, indicated that 50 percent were migrants. Year-round residents often are found below $40^{\circ} \mathrm{N}$.

\section{Food Habits}

Starlings are omnivorous, with a natural diet of invertebrates and wild fruits. A major portion of their invertebrate diet consists of coleopteran (beetle) and lepidopteron (butterfly and moth) larvae foraged from soils of lawns and fields. Ripening fruits, including pokeberry (Phytolacca americana) and Russian olive (Elaeagnus angustifolia), are eaten in summer and fall.

Access to natural foods lessens by early fall, and starlings switch to human-supplied foods, including ripening corn, commercial fruits, distiller's grain, suet, pet food and livestock feed. They also forage on refuse and spillage at landfills, eateries and food processing plants.

Starlings develop a preference for high-energy fatty foods during winter. To support nutritional and energetic needs during colder periods, starlings eat an ounce or more of food per day. During winter, caged starlings in Kansas ate $1 \frac{1 / 4}{4}$ ounces of poultry pellets per bird per day. When fed a similar type pellet with a higher content of animal fat, starlings ate 0.6 ounces per bird per day, indicating that starlings were efficiently digesting animal fats.

Starlings can eat remarkable amounts of fruit because of their inefficiency in digesting high-carbohydrate foods. Caged starlings allowed to feed at liberty on blueberries ate 9 ounces per bird per day, nearly 3 times their bodyweight. Similarly, starlings are quite voracious with grapes, eating nearly 14 ounces per bird per day.

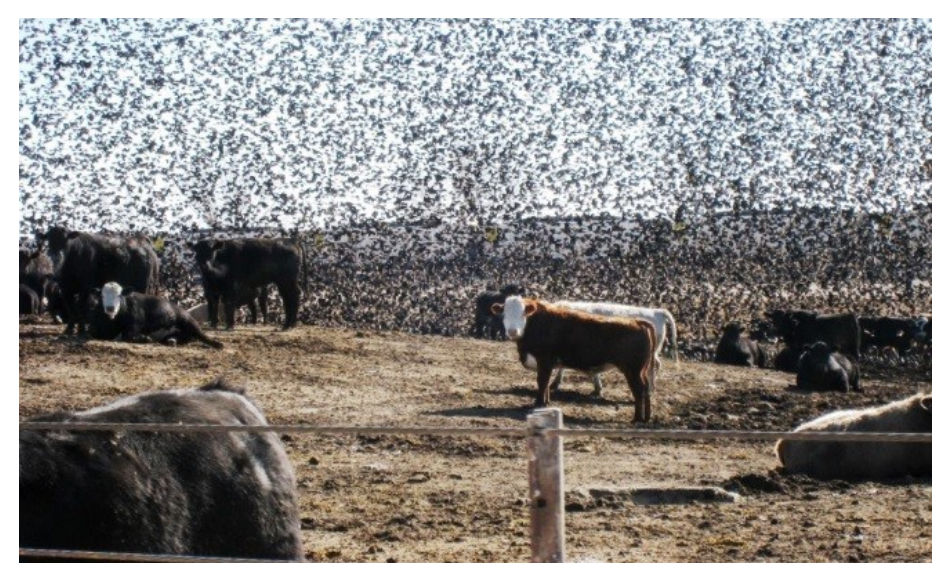

Figure 18. Starlings at a cattle feedlot. 


\section{Legal Status}

European starlings are not protected by the Migratory Bird Treaty Act (MBTA). Moreover, no state laws in the U.S. directly protect them. Methods of take in urban and suburban areas may be regulated by local ordinances. At the state level, natural resource agencies may require collection permits, even for an unprotected species like the starling. Before initiating a control program, always check with state and local resource management agencies, health departments and law enforcement agencies. 


\section{Acknowledgements}

Figure 1. Photo by Hays Cummings, Miami University

Figure 2, 10 and 11. Photos by Susan Wieferich

Figure 3. Photo by W. MacDonald

Figure 4. Photo by Jim Carlson, USDA-APHIS Wildlife Services

Figure 5. Photo by Nick Dunlop

Figure 6, 13, and 18. Photos by James Thiele, USDA-APHIS Wildlife Services

Figure 7. Photo by Dionne Orr, USDA-APHIS Wildlife Services

Figure 8. Photo by Garrett Unrein, USDA-APHIS Wildlife Services

Figure 9 and 15. Photo by USDA-APHIS Wildlife Services

Figure 12. Photo by M. Smith

Figure 14. Photo by Megan Shave

Figure 16. Map by National Audubon Society

Figure 17. Photo by Channing Howard

We thank J. Glahn for his contributions from the previous version of this publication that was part of Prevention and Control of Wildlife Damage. Editors, Scott E. Hygnstrom, Robert M. Timm, Gary E. Larson. 1994. University of NebraskaLincoln. 2 vols.

\section{Glossary}

CAFOs: concentrated animal feeding operations; feedlots

Omnivorous: Eats both plants and animals

Prebaiting: The practice of providing non-treated bait to animals so they become accustomed to it, prior to providing treated or toxic bait.

Mandible: either the upper or lower part of a bird's beak

Migratory restlessness: Anxiety or restlessness experienced by animals prior to migration; occurs primarily in species that migrate long distances

Take: Pursue, hunt, shoot, wound, kill, trap, capture, or collect a protected species, or attempt to pursue, hunt, shoot, wound, kill, trap, capture, or collect a protected species

\section{Key Words}

Confined Animal Feeding Operations, CAFO, dairies, disease, DRC-1339, European starlings, feedlots, fruit damage, invasive species, sweet corn damage, urban roosts

\section{Disclaimer}

Wildlife can threaten the health and safety of you and others in the area. Use of damage prevention and control methods also may pose risks to humans, pets, livestock, other non-target animals, and the environment. Be aware of the risks and take steps to reduce or eliminate those risks.

Some methods mentioned in this document may not be legal, permitted, or appropriate in your area. Read and follow all pesticide label recommendations and local requirements. Check with personnel from your state wildlife agency and local officials to determine if methods are acceptable and allowed.

Mention of any products, trademarks, or brand names does not constitute endorsement, nor does omission constitute criticism.

\section{Citation}

Homan, H.J., R.J. Johnson, J.R. Thiele, and G.M. Linz. 2017. European Starlings. Wildlife Damage Management Technical Series. USDA, APHIS, WS National Wildlife Research Center. Ft. Collins, Colorado. 26p. 


\section{Resources}

Anderson, A., C.A. Lindell, K.M. Moxcey, W.F. Siemer, G.M. Linz, P.D. Curtis, J.E. Carroll, C.L. Burrows, J.R. Boulanger, K.M.M. Steensma, and S.A. Shwiff. 2013. Bird damage to select fruit crops: The cost of damage and the benefits of control in five states. Crop Protection 52:103-109.

Carlson, J.C., A.B. Franklin, D.R. Hyatt, S.E. Pettit, and G.M. Linz. 2011. The role of starlings in the spread of Salmonella within concentrated animal feeding operations. Journal of Applied Ecology 48:479-486.

Cernicchiaro, N., D.I. Pearl, S.A. McEwen, L. Harpster, H.J. Homan, G.M. Linz, and J.T. LeJeune. 2012. Association of wild bird density and farm management factors with the prevalence of E. coli 0157 in dairy herds in Ohio (2007 -2009). Zoonoses and Public Health 59:320-329.

European starling general information: http://www.birds.cornell.edu/onlineguide/

Gaukler, S. M., H.J. Homan, G.M. Linz, and W.J. Bleier. 2012. Using radio-telemetry to assess the risk European starlings pose in pathogen transmission among feedlots. Human-Wildlife Interactions 6:30-37.

Glahn, J.F., D.J. Twedt, and D.L. Otis. 1983. Estimating feed loss from starling use of livestock feed troughs. Wildlife Society Bulletin 11:366-372.

Homan, H.J., A.A. Slowick, L.B. Penry, G.M. Linz, and W. Anderson. 2012. Site use of European starlings wintering in central New Jersey. Vertebrate Pest Conference 25:230-234.

Homan, H.J., J.T. LeJeune, D.L. Pearl, T.W. Seamans, A.A. Slowik, M.R. Morasch, and G. M. Linz. 2013. Use of dairies by post-reproductive flocks of European starlings. Journal of Dairy Science 96:4487-4493.

Homan, H.J., R.S. Stahl, and G.M. Linz. 2013. Comparison of two models for estimating mortality from baitings with Compound DRC-1339 Concentrate avicide. Crop Protection 45:71-75.

Homan, H.J., R.S. Stahl, and G.M. Linz. 2011. Comparing a bioenergetics model with feeding rates of caged European starlings. Journal of Wildlife Management 75:126-131.

Homan, H.J., G.M. Linz, S. Beckerman, A.G. Duffiney, T.D. Halstead. 2010. European starling preferences for bait substrates used in DRC-1339 applications. Human Wildlife Conflicts 4:25-31.

Homan, H.J., A.A. Slowik, L.B. Penry, G.M. Linz, M.J. Bodenchuk, and R.L. Gilliland. 2010. Site use of European starlings captured and radio-tagged at Texas feedlots during winter. Vertebrate Pest Conference 24:250-256.

Homan, H.J., R.S. Stahl, J.J. Johnston, and G.M. Linz. 2005. Estimating DRC-1339 mortality using avian bioenergetics: a case study of the European starlings. Wildlife Damage Management Conference 11:202-208.

Linz, G.M., H.J. Homan, S.M. Gaukler, L.B. Penry, and W.J. Bleier. 2007. European starlings: a review of an invasive species with far-reaching impacts. Management of Invasive Species Conference, August 7-9, 2007, Fort Collins, Colorado, USA. Proceedings of the Management of Invasive Species Conference. Pg. 378-386. 
Shwiff, S.A., J.C. Carlson, J.H. Glass, J. Suckow, M.S. Lowney, K.M. Moxcey, B. Larson, and G.M. Linz. 2012.

Producer survey of bird-livestock interactions in commercial dairies. Journal of Dairy Science 95:6820-6829.

Sodium Lauryl Sulfate Technical Note: https://www.aphis.usda.gov/wildlife damage/nwrc/publications/

Tech_Notes/TN_SodiumLaurylSulfate.pdf

Starling nest-box trap: http://www.chuckspurplemartinpage.com/startrap.htm

Swirski, A.L., D.L. Pearl, M.L. Williams, H.J. Homan, G.M. Linz, N. Cernicchiaro, and J.T. LeJeune. 2014. Spatial epidemiology of Escherichia coli 0157:H7 in dairy cattle in relation to night roosts of Sturnus vulgaris (European starling) in Ohio, USA (2007-2009). Zoonoses and Public Health:1-9.

Thiele, J.R., H.J. Homan, G.M. Linz, and G.W. Unrein. 2012. Developing an effective management plan for starlings roosting in downtown Omaha, Nebraska. Proceedings of the Wildlife Damage Management Conference 14:87-90. 


\section{Appendix 1}

Damage Management Methods for European Starlings

\begin{tabular}{|c|c|}
\hline Type of Control & Available Management Options \\
\hline Exclusion & $\begin{array}{l}\text { - } \text { Mesh netting or screening }<19 / 16^{\prime \prime} \text { vinyl strip doors } \\
\text { - } \quad \text { Canted (greater than or equal to } 45^{\circ} \text { ) or spiked ledges } \\
\text { - } \quad \text { Nest box designs that prevent starling occupancy } ;<19 / 16 \text { " diameter entry hole }\end{array}$ \\
\hline $\begin{array}{l}\text { Frightening Devices } \\
\text { and Agents }\end{array}$ & $\begin{array}{l}\text { - } \text { Propane cannons and associated pyrotechnics } \\
\text { - } \quad \text { Aerial predator decoys and kites, flash tape, scare-eye balloons, scarecrows, lasers } \\
\text { - } 4 \text {-aminopyridine (Avitrol } \circledast \text { ) } \\
\text { - } \quad \text { Falconry }\end{array}$ \\
\hline Habitat Modification & $\begin{array}{l}\text { - Manage tree stands and wetland emergents } \\
\text { - } \text { Automatic feeders or hinged-lid feeders } \\
\text { - } \text { Feed storage sites that can be closed or covered } \\
\text { - } \text { Reduce water levels in watering troughs } \\
\text { - Large or unusually shaped food pellets }\end{array}$ \\
\hline Repellents & $\begin{array}{l}\text { - } 9,10 \text { anthraquinone (AG), registered as Avipel® (seed treatment) } \\
\text { - } \quad \text { Methyl anthranilate (fruit crops) } \\
\text { - } \quad \text { Polybutenes (perch deterrents) }\end{array}$ \\
\hline Shooting & $\begin{array}{l}\text { - } 12 \text { gauge shotgun with \#6 steel shot } \\
\text { - } \quad \text { Pellet gun }\end{array}$ \\
\hline Toxicants & Compound DRC-1339 Concentrate (Restricted use pesticide) \\
\hline Trapping & Cage and nest box traps \\
\hline Other & Sodium lauryl sulfate (wetting agent for roosts); kestrel nest boxes \\
\hline
\end{tabular}




\section{Appendix 2}

\section{Estimating Cost-Benefit Ratios for Bird Management}

A rule-of-thumb for evaluating the economic feasibility of a management method involves adding pretreatment costs of bird damage and the amortized costs of deploying a method and then subtracting the savings gained from applying the treatment. The resulting sum must be greater than the depreciated costs. A cost:benefit ratio of 1:2 or greater should be expected. Assuming all crop inputs were made before damage occurred, a general formula for agricultural and fruit crops would be as follows (using acres as the areal unit):

\section{$(A \times B+C / D)-([A \times B]-[A \times E)]>F$}

\section{Where}

$A=$ economic production per acre (i.e., price received at sale)

$B=$ proportion of anticipated bird damage under no treatment

$\mathrm{C}=$ amortized cost of using method (including labor, equipment and maintenance)

$\mathrm{D}=$ acres of crop protected by method

$E=$ proportion of damage after implementing treatment

$F=$ depreciated value of method or other accounting for lost value and function 